\title{
Influence of Environmental and Microclimate Factors on the Coffee Beans Quality (C. canephora): Correlation between Chemical Analysis and Stable Free Radicals
}

\author{
André Luíz Alves1, Marcio Solino Pessoa1*, Paulo Eduardo Narcizo de Souza², \\ Fábio Luís Partelli', Paulo Sérgio Moscon¹, Edson Correa da Silva ${ }^{3}$, André Oliveira Guimarães ${ }^{3}$, \\ Eduardo Perini Muniz¹, Patrícia Fontes Pinheiro4, Flávio Meira Borém5 , Paulo César Morais ${ }^{2,6}$ \footnotetext{
Mateus, Brazil

${ }^{2}$ Universidade de Brasília, Instituto de Física, Núcleo de Física Aplicada, Brasília DF, Brazil

${ }^{3}$ Laboratório de Ciências Físicas, Centro de Ciências e Tecnologia, Universidade Estadual Norte Fluminense, Campos dos Goytacases, Brazil

${ }^{4}$ Departamento de Química e Física, Universidade Federal do Espírito Santo, Alto Universitário, Alegre, Brazil

${ }^{5}$ Departamento de Engenharia, Universidade Federal de Lavras, Lavras, Brazil

${ }^{6}$ School of Chemistry and Chemical Engineering, Anhui University, Hefei, China

Email: *marcio.pessoa@ufes.br
} \\ ${ }^{1}$ Departamento de Ciências Naturais, Universidade Federal do Espírito Santo, Centro Universitário Norte do Espírito Santo, São
}

How to cite this paper: Alves, A.L., Pessoa, M.S., de Souza, P.E.N., Partelli, F.L., Moscon, P.S., da Silva, E.C., Guimarães, A.O., Muniz, E.P., Pinheiro, P.F., Borém, F.M. and Morais, P.C. (2018) Influence of Environmental and Microclimate Factors on the Coffee Beans Quality (C. canephora): Correlation between Chemical Analysis and Stable Free Radicals. Agricultural Sciences, 9, 1173-1187.

https://doi.org/10.4236/as.2018.99082

Received: August 15, 2018

Accepted: September 25, 2018

Published: September 28, 2018

\begin{abstract}
The present study reports a physicochemical comparison of shade-grown and sun-grown coffee beans, under unripe, rip and roasted-ripe conditions, using electrical conductivity measurements, electron paramagnetic resonance (EPR), infrared spectroscopy (FTIR), and high performance liquid chromatography (HPLC). Moreover, the assessed physicochemical parameters were compared with organoleptic evaluations based on the Coffee Quality Institute protocol. The values found for electrical conductivity, leached potassium, and stable free radicals were respectively $29 \%, 31 \%$, and $350 \%$ higher for shade-grown coffee beans, whereas polyphenol oxidase enzymatic activity was $23 \%$ lower. By contrast, FTIR and HPLC measurements identified higher chlorogenic acid and lipid contents in sun-grown coffee beans. Importantly, the sensorial grade attributed to roasted-ripe grains was $12 \%$ higher for sun-grown coffee. Our findings suggest that shade-grown coffee beans have undergone microorganismal activity and undesired fermentation during cultivation, which resulted in lower coffee quality. A correlation between a set of selected physicochemical properties and organoleptic properties was robustly
\end{abstract}


Copyright (c) 2018 by authors and Scientific Research Publishing Inc. This work is licensed under the Creative Commons Attribution International License (CC BY 4.0).

http://creativecommons.org/licenses/by/4.0/ established and could be used in the development of future coffee bean quality control protocols.

\section{Keywords}

Sun-Grown Coffee, Shade-Grown Coffee, Fermentation, EPR, FTIR, HPLC

\section{Introduction}

The genus Coffea $(C)$ comprises at least 124 species, of which $C$. arabica and $C$. canephora (Robusta) are economically important [1]. Although C. arabica is the more widely farmed species, cultivation of $C$. canephora also contributes significantly to worldwide coffee production. In 2015, world coffee production exceeded 144.7 million bags, of which 41.5 million bags were of C. canephora origin. Much of the production from C. canephora occurs in countries considered as having emerging economies, with Brazil being the second largest producer [2] [3].

Coffee quality and productivity vary according to shading density during cultivation [4] [5]. The effect of shading on cultivation depends on an interaction with other parameters, such as temperature, humidity, rainfall, topography, and altitude. However, the influences of these interactions are somewhat controversial. For example, Dandengo et al. (2014) reported that saplings had faster growth and better quality when cultivated in shade than in full sunlight [6]. Additionally, recent studies in tropical regions have shown that moderate shading protects the plant from high solar radiation, reduces temperature, and helps moisture retention, thus producing beans with improved organoleptic qualities [6] [7] [8]. By contrast, Morais et al. (2003) reported that high shading density significantly decreased the absorbed photosynthetic radiation, and had a negative impact on productivity [9]. Bosselmann et al. (2009) found that in high altitudes regions, such as Colombia, shaded cultivation produced an inferior quality beverage, reduced the number of fruits per plant, and favored the occurrence of the pest species coffee berry borer (CBB), Hypothenemus hampei Ferrari [10].

In general, the occurrence of a pest such as CBB is favored under humid conditions because of shading and/or frequent rainfall [11] [12] [13] [14]. The worst damage occurs when CBB larvae and adult females feed on both pulp and bean to cause injuries that allow secondary infections by fungi and bacteria, resulting in undesirable fermentation in the fruit. Fermentation causes physicochemical changes in beans and degrades chemical components of great importance for good coffee quality [15] [16]. Recently, Thapa and Lantinga (2017) suggested that the prevalence of the coffee white stem borer (CWSB), Xylotrechus quadripes (Chevrolat) (Coleoptera: Cerambycidae), a major coffee pest in Asia, Africa, and America, is significantly higher for sun-grown (60\%) compared to 
shade-grown (40\%) coffee plants [17]. The frequency of infested plants showed a significant negative correlation with the number of permanent shading trees in plantations, suggesting that developing a stand of permanent shading trees could be a potential strategy for management of CWSB.

In addition to economic effects, shading can have environmental advantages. Coffee is an important tropical commodity and is often grown in high-priority biological conservation areas. Buechley et al. (2015) studied bird communities in farms with shaded coffee plants and in moist evergreen Afromontane forest in Ethiopia [18]. Although species diversity did not differ between the shaded plantation and the forest, the former had more than double the species richness of the forest sites; indeed, all but one of nine Palearctic migratory species were found only in the shaded plantation, indicating that it was perhaps a more "bird-friendly" approach to cultivating coffee. This finding is important with regard to efforts to conserve forest birds in Africa. It also suggests benefits to the farmers in shaded plantations as they may have increased avian pest regulation and be able to obtain biodiversity-friendly coffee certification.

Coffee bean quality can be ascertained by assessment of physicochemical and compositional characteristics, such as sugar content, carbohydrates, lipids, chlorogenic acid (CGA), and caffeine [19] [20] [21] [22] [23]. The relative proportion of these components varies with the method of cultivation, storage, and roasting temperatures [23] [24] [25] [26]. Some of the above-mentioned compounds, such as sugars, have stable free radicals [27] [28]; importantly, the free radical content is related to chemical processes that define beverage quality [29] [30] [31] [32]. The effects of oxi on stable free radical content in coffee beans have unfortunately been little investigated.

As stated above, there are conflicting results regarding the impact of sun and shade on coffee bean quality. Therefore, it is important to considering the dependence of coffee bean and beverage qualities in regard to specific environmental aspects of each production region. It is expected that environments with high pluviometric precipitation can favor the presence of microorganisms, affecting the quality of the beans submitted to different conditions of solar exposure. In the present study, coffee (C. canephora) was cultivated either with full sun exposure or under shading from rubber trees (Hevea brasiliensis); physicochemical parameter, in particular, stable free radical assessment, was compared in the two groups of plants. Sensorial investigations of the roasted coffee beans were also carried. The plants were grown during a period with frequent rainfall, coinciding with fruit maturation, in the northern region of Espírito Santo State, Brazil.

\section{Materials and Methods}

\subsection{Growth and Processing}

Coffee samples used in the present study were produced in a farm in the municipality of Jaguaré, Espírito Santo State, Brazil $\left(18^{\circ} 56^{\prime} \mathrm{S}, 39^{\circ} 58^{\prime} \mathrm{W}\right.$, at $70 \mathrm{~m}$ alti- 
tude). The experiment consisted of a coffee crop grown under full sun (sun-grown coffee) with $3.0 \times 1.1 \mathrm{~m}$ spacing (3030 plants/ha) and a coffee crop intercropped with rubber trees (shade-grown coffee) planted at $7.8 \times 2.3 \mathrm{~m}$ (557 plants/ha). Both crops were aligned in an East/West direction; the coffee trees were planted in late 2006, while the rubber trees ( H. brasiliensis) were planted in late 2007. Coffee berry harvesting was performed manually between May and July 2014, when approximately $80 \%$ of the berries were ripe. A description of the growing region microclimate is available in Araújo et al. (2016) [5]; the shading resulted in an average decrease in luminosity from 1240 to 335 lumens/ $/ \mathrm{ft}^{2}$ (decrease of $\sim 73 \%$ ) in the summer and from 1665 to 227 lumens/ $\mathrm{ft}^{2}$ (decrease of $\sim 88 \%$ ) in the winter and therefore had the characteristics of dense shading.

The growing region has a flat topography and is subjected to a warm tropical climate [33] with an annual average temperature of $23^{\circ} \mathrm{C}$ and precipitation of $1250 \mathrm{~mm}$ [5]. The number of rainy days per month during the coffee bean maturation period is shown in Figure 1-data provided by the meteorological station of the municipality of São Mateus-ES; the period over which this experiment was conducted and the samples collected was exceptionally rainy. After harvest, the beans were placed in soil drying ovens for 7 days at a temperature of $40^{\circ} \mathrm{C}$. Ripe beans were been selected, as these are the ones used for coffee beverages, and roasted using a conventional industrial roaster. Thus, three groups of bean were analyzed in this study: unripe, ripe, and roasted-ripe.

\subsection{Physicochemical Parameters}

For electrical conductivity (EC) and leached potassium (LK) analysis, two samples of 50 beans were weighed, with a resolution of $1 \mathrm{mg}$, and each sample was immersed in $75 \mathrm{~mL}$ distilled water. The resulting soaking liquid were taken to biochemical oxygen demand (BOD) with forced ventilation for 5 hours, at $25^{\circ} \mathrm{C}$; the EC measurements of the soaking water were obtained using a BEL W12D apparatus while the LK measurements were recorded using a Digimed NK-2002 photometer.

Determination of total sugar concentration was performed by Antrona's method [34] using UV-Vis spectroscopy with the wavelength set at $620 \mathrm{~nm}$, taking a fructose standard curve $(100 \mathrm{mg} / \mathrm{mL})$ in the interval $0-100 \mathrm{mg}$ with related reference.

For assessment of polyphenol oxidase (PPO) activity, $5 \mathrm{~g}$ of ripe beans were powdered in liquid nitrogen and placed in $40 \mathrm{~mL}$ of potassium aqueous phosphate solution $(0.1 \mathrm{M}, \mathrm{pH}$ 6). Subsequently, the sample was stirred for $5 \mathrm{~min}$ and then passed through a vacuum filter (Whatman no. 1). PPO activity was estimated by the method described by Ponting and Joslyng (1948) [35], using a sample extract without DOPA (L-3,4-dihydroxyphenyl-alanine) with related reference. The results were expressed as $\mu \mathrm{mol} / \mathrm{min} / \mathrm{g}$ of dry mass.

Free radicals in all samples were analyzed by electron paramagnetic resonance (EPR) using a Bruker spectrometer model Elexsys 500 equipped with an X-band 




Figure 1. Number of rainy days in the period January-July of 2014, in the region where the coffee was cultivated, city of Jaguaré, Espírito Santo State, Brazil $\left(18^{\circ} 56^{\prime} \mathrm{S}, 39^{\circ} 58^{\prime} \mathrm{W}\right.$, at $70 \mathrm{~m}$ altitude) (CEUNES, 2016).

cylindrical cavity operating at $9.8 \mathrm{GHz}$ (modulation amplitude/frequency set at 1 $\mathrm{G} / 100 \mathrm{kHz}$ and microwave power of $0.6 \mathrm{~mW}$ ). Room-temperature EPR spectra were recorded in the field range from 344 to $360 \mathrm{mT}$, in an air atmosphere. In order to obtain an average sample spectrum, at least five beans were randomly selected from each crop. All spectra were normalized by sample mass and the resonance field, $g$-factor and free radical content were assessed by fitting each spectrum using a Lorentzian-type function [28] [36].

CGA and caffeine content determinations were performed by high performance liquid chromatography (HPLC) using a Shimadzu chromatograph (Prominence) equipped with a Shimadzu VP-ODS Slim-pack C18 reverse phase column ( $250 \mathrm{~mm}$ long $\times 4.6 \mathrm{~mm}$ internal diameter). The hot extraction method was applied to $0.5 \mathrm{~g}$ of each ground coffee sample, in $100 \mathrm{~mL}$ of ultrapure water (Milli-Q), under constant stirring for $20 \mathrm{~min}$, at $80^{\circ} \mathrm{C}$. HPLC operation conditions were $1 \mathrm{~mL} / \mathrm{min}$ flux, mobile phase with methanol, water and acetic acid (20:80:1), column temperature set at $40^{\circ} \mathrm{C}$, and reading wavelength of $272 \mathrm{~nm}$. Quantification was performed by the external standard method using a calibration line obtained from chromatogram peak areas at $272 \mathrm{~nm}$ from the CGA standard solution 5-caffeoylquinic (5-CQA) and caffeine (1,3,7-trimetilxantina) from Sigma-Aldrich [22] [37]. Recorded data are presented as composite mass (in grams) for each $\mathrm{kg}$ of coffee beans (dry ground).

Fourier transform infrared spectroscopy (FTIR) measurements were performed using an Agilent Cary 630 spectrometer operating in ATR (attenuated 
total reflectance) mode with a diamond crystal, 60 scans, and resolution of 2 $\mathrm{cm}^{-1}$. Ten measurements were recorded for each sample and the spectral average was subtracted from a seven point baseline before normalization.

Statistical analysis was performed using the GENES software package with a completely randomized design [38]. For determination of the physicochemical properties, CGA and 5-CQA Turkey and Skott-Knott tests were applied at 5\% probability. The coefficient of variation $(\mathrm{CV})$ and standard deviation were used to check for significant statistical differences.

Sensory quality of the beverage (cup test/taste) was evaluated by a company specialized in Robusta cup tests using criteria established by the Coffee Quality Institute [39].

\section{Results and Discussion}

\subsection{Physicochemical Parameters}

The estimates for the values of the various tested parameters from ripe beans are shown in Table 1. The shade-grown coffee had lower total sugar values; this is an undesirable feature as the sugars are responsible for the caramel flavor of coffee beverage and increase its sweetness [22] [40]. Similar results were obtained by Somporn et al. (2012) in an HPLC analysis of shade-grown coffee beans [41].

For shade-grown coffee samples, EC and LK values were $29 \%$ and $31 \%$ higher compared with sun-grown coffee samples. As reported by Bellé et al. (2014), LK values are related to the membrane damages; the increase in the EC is expected since the leached potassium $\left(\mathrm{K}^{+}\right)$promotes the increase of cations in the solute [42]. The PPO activity of shade-grown coffee was about $23 \%$ lower than that of sun-grown coffee. This difference likely results from exhaustion of the substrate supply, mainly CGA, by the enzyme. It may also reflect enzyme inactivation during oxidation of the CGA into quinones. Cellular membrane damage is a consequence of PPO mediated degradation of CGA [43] [44] [45] and, as already reported by Franca et al. (2005), an increase in cellular damage in coffee beans lowers the quality of the beans [24].

Table 1. Average values of electrical conductivity (EC), leached potassium (LK), total sugar (TS) and polyphenol oxidase (PPO) enzymatic activity along with their respective coefficient of variation (CV) for the coffee samples under study.

\begin{tabular}{|c|c|c|c|}
\hline \multicolumn{4}{|c|}{ Growth conditions } \\
\hline & Sun-coffee & Shade-coffee & $\mathrm{CV}(\%)$ \\
\hline TS (g/kg) & $63.2 \pm 3.3^{\mathrm{a}}$ & $47.2 \pm 2.5^{\mathrm{b}}$ & 5.28 \\
\hline $\mathrm{EC}(\mu \mathrm{S} / \mathrm{cm} \times \mathrm{g})$ & $20.5 \pm 3.4^{\mathrm{a}}$ & $26.3 \pm 4.4^{\mathrm{b}}$ & 17.02 \\
\hline LK (g/kg) & $0.13 \pm 0.03^{\mathrm{a}}$ & $0.17 \pm 0.03^{\mathrm{b}}$ & 22.37 \\
\hline PPO $(\mu \mathrm{mol} / \mathrm{min} / \mathrm{g})$ & $35.6 \pm 1.4^{\mathrm{a}}$ & $27.3 \pm 1.1^{\mathrm{b}}$ & 3.99 \\
\hline
\end{tabular}

${ }^{\mathrm{a}, \mathrm{b}}$ Averages followed by different letters on the same row differ statistically by Tukey's test $(P<0.05)$. 
Intercropping of $C$. canephora with rubber trees provides dense shading and promotes changes in microclimate conditions that, in combination with frequent rainfall, reduce water evaporation while keeping more moisture in the fruit for a longer period of time [5]. However, these conditions also favor an increase in pathogenic microorganism populations as well attacks by herbivorous insects, such as CBB, and can therefore promote increased damage to beans [12] [14] [45]. Furthermore, microorganisms produce enzymes that cause fermentation events by degrading mucilage in the fruit; this increased fermentation promotes physicochemical changes, such as reductions in water, simple sugar contents, and formation of aroma and flavored precursors [15]. The low total sugar values obtained for shade-grown coffee is strong evidence of the occurrence of increased fermentation under shading conditions.

\subsection{Electron Paramagnetic Resonance}

Figure 2 shows the mass normalized EPR spectra for the ground coffee beans. Assessed $g$-factors were in the range of 2.0043 to 2.0045 , with a peak-to-peak line width of about $0.65 \mathrm{mT}$; these measurements are characteristic of stable free radical species previously described in coffee beans [36]. Quantitative assessment of stable free radicals was performed by double integration of the as-fitted first Lorentzian derivative and the results are shown in Table 2. We found that 1) the typical free radical signal from the ripe beans was detectable only in shade-grown coffee (Figure 2(a)); 2) free radicals from the unripe beans were observed in both cultivation groups although their level was about $260 \%$ higher in shade-grown coffee (Figure 2(b)); 3 ) as expected, the roasting process, carried out only for ripe beans (Figure 2(a)), resulted in an increased EPR signal for free radicals due to melanoidin formation through the Maillard and caramelization reactions [27] [36], with an approximately $40 \%$ higher level for shade-grown coffee (Figure 2(c)); 4) free radical intensities were consistently higher for the shade-grown coffee samples (Table 2).

Our findings suggest that the higher humidity environment experienced by shade-grown coffee promoted an increase in formation of stable free radicals. Yeretzian et al. (2012) reported that free radical content during storage could increase due to oxidative processes in the surface fraction exposed to air [32]. The results of that study are in agreement with our suggested interpretation of our physicochemical measurements, namely, that damage due to the activity of microorganisms and insects increased the surface fraction of beans exposed to air, favoring the formation of free radicals. Additionally, besides involving sugars [15], fermentation processes are favored by moist environments and thus we propose that fermentation might play a key role in production of free radicals.

The highest content of free radicals was observed in unripe beans and reflects their metabolism and chemical composition, which are different from those of ripe beans. Montavón et al. (2003) reported that unripe beans are relatively more 
(a) Ripe beans



(c) Roasted ripe beans

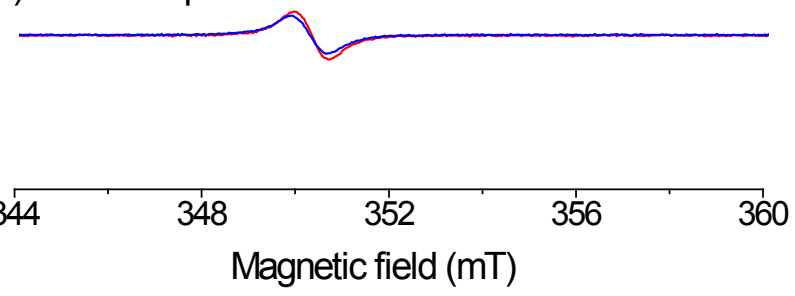

Figure 2. Room-temperature EPR spectra of the shade-grown coffee (red) and sun-grown coffee (blue): (a) ripe, (b) unripe and (c) roasted-ripe.

Table 2. Intensity values (double integral of EPR spectra) for ground coffee beans: ripe, unripe, and roasted-ripe obtained for shade-grown and sun-grown coffee.

\begin{tabular}{ccc}
\hline \multirow{2}{*}{ Item/beans types } & \multicolumn{2}{c}{ Intensity (a.u) } \\
\cline { 2 - 3 } & Shade-grown & Sun-grown \\
\hline Ripe & $0.64 \pm 0.7$ & $\mathrm{ND}$ \\
Unripe & $5.0 \pm 0.8$ & $1.4 \pm 0.3$ \\
Roasted-ripe & $1.4 \pm 0.3$ & $1.0 \pm 0.2$ \\
\hline
\end{tabular}

ND: non-detected signal.

sensitive to oxidation and that oxidation defense mechanisms become more efficient as the beans mature [46].

\subsection{FTIR and HPLC}

Typical FTIR spectra of coffee beans, obtained for all the analyzed samples, are shown in Figures 3(a)-(c). Absorption bands in the 900 to $1450 \mathrm{~cm}^{-1}$ region are associated with $\mathrm{C}-\mathrm{H}, \mathrm{C}-\mathrm{O}, \mathrm{C}-\mathrm{N}$, and P-O vibrations [47]. CGA gives a strong absorption in the $1000-1450 \mathrm{~cm}^{-1}$ region. Carbohydrates also exhibit several absorption bands in the $700-1500 \mathrm{~cm}^{-1}$ range [47] [48]. Our analyses indicated that sun-grown coffee beans showed higher FTIR absorption intensities, suggesting an increased content of the above-mentioned compounds.

An FTIR band peaking around $1745 \mathrm{~cm}^{-1}$ is characteristic of carbonyl $(\mathrm{C}=\mathrm{O})$ stretching; this chemical bond is found in acids, esters, and other classes of 


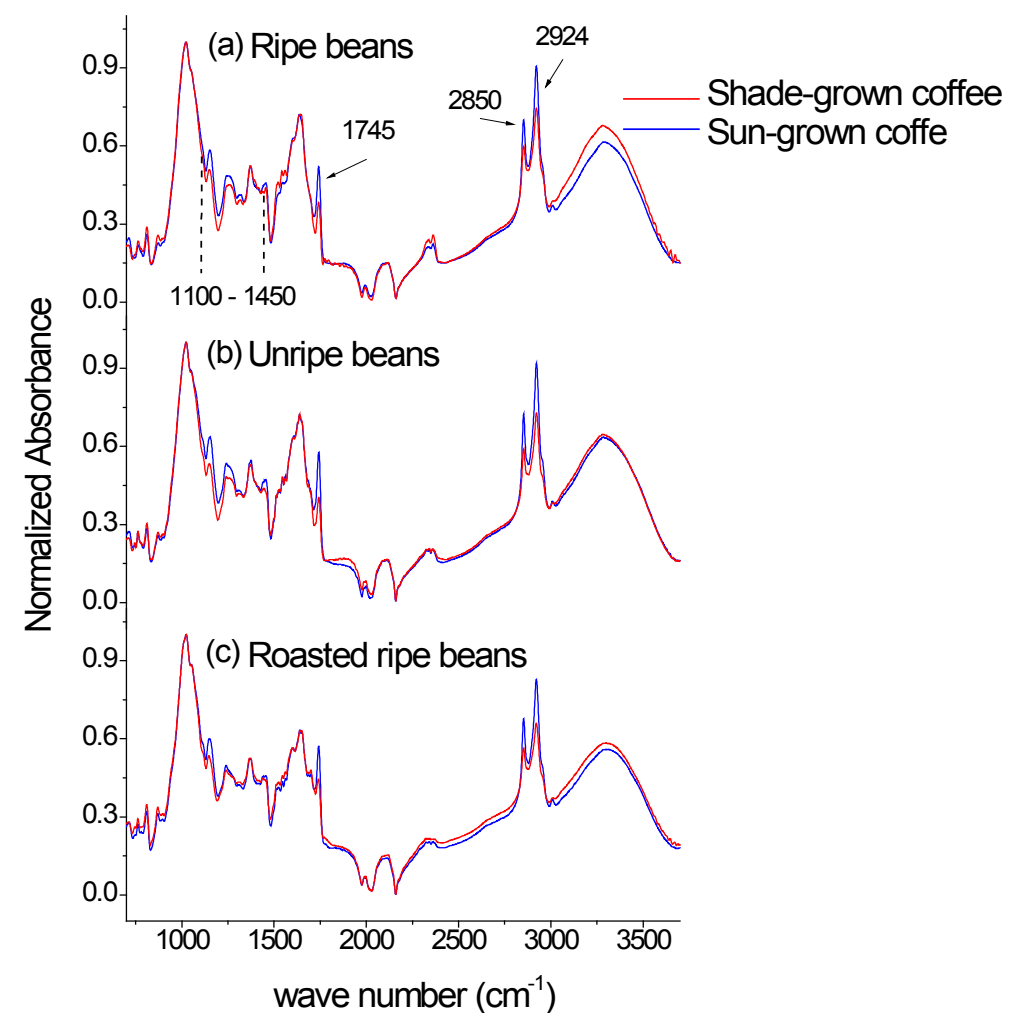

Figure 3. Infrared spectra (FTIR) of the shade-grown coffee (red) and sun-grown coffee (blue): (a) ripe, (b) unripe and (c) roasted-ripe.

organic compounds associated with lipids [48] [49]. The presence of methyl and methylene groups is confirmed by two sharp peaks at $2850 \mathrm{~cm}^{-1}$ and $2924 \mathrm{~cm}^{-1}$, attributed to symmetric and asymmetric stretching of $\mathrm{C}-\mathrm{H}$ bonds in aliphatic chains, respectively. All of these peaks can likely be attributed to lipids [48] [49] [50]. Additionally, the absorption band around $2850 \mathrm{~cm}^{-1}$ was related to $\mathrm{C}-\mathrm{H}$ stretching in methyl $\left(\mathrm{CH}_{3}\right)$ groups, which are found in caffeine [51]. Therefore, the higher areas of these bands in the sun-grown coffee spectra must be due to higher concentrations of lipids and/or caffeine.

The FTIR technique allows qualitative evaluation of chemical compounds in the coffee beans samples. However, a quantitative evaluation of caffeine and 5-CQA contents, corresponding to $76 \%-84 \%$ of the total CGA, was obtained using the HPLC technique [52]. The results showed that there was 1) a higher content of 5-CQA in sun-grown coffee, about $10 \%$ and $21 \%$ for the ripe and unripe samples, respectively; 2) a higher content (about 12\%) of caffeine in ripe shade-grown coffee; and 3) that the roasting process decreased 5-CQA values, i.e., to $70 \%$ and $85 \%$ for sun-grown coffee and shade-grown coffee samples, respectively (Table 3 ). There were no significant differences between the two samples of unripe beans on a Scott-Knott test at the 5\% probability level. The significant decrease in 5-CQA content could be attributed to the degradation of CGA in phenolic compounds and volatile products [25] [53] [54]. Nonetheless, we found that the 5-CQA content was higher for shade-grown coffee. 
Table 3. Average values (in $\mathrm{g} / \mathrm{kg}$ dry basis) of the 5-CQA acid and caffeine contents measured by HPLC in ground coffee beans: ripe, unripe, and roasted-ripe cultivated under shaded and full sun conditions.

\begin{tabular}{cccc}
\hline Bean type & Compost (g/kg dry basis) & Shade-grown & Sun-grown \\
\hline \multirow{2}{*}{ Ripe } & 5-CQA CQ $^{*}$ & $44.8 \pm 3.3^{\mathrm{a}}$ & $49.3 \pm 3.6^{\mathrm{b}}$ \\
& caffeine & $17.2 \pm 0.9^{\mathrm{b}}$ \\
Unripe & 5 -CQA & $19.3 \pm 1.0^{\mathrm{a}}$ & $45.0 \pm 3.3^{\mathrm{b}}$ \\
& caffeine & $37.3 \pm 2.7^{\mathrm{a}}$ & $19.7 \pm 1.0^{\mathrm{b}}$ \\
Roasted-ripe & 5 -CQA & $21.3 \pm 1.1^{\mathrm{a}}$ & $15.0 \pm 1.1^{\mathrm{b}}$ \\
caffeine & $6.9 \pm 0.5^{\mathrm{a}}$ & $19.8 \pm 1.0^{\mathrm{a}}$ \\
CV $(\%)$ & ${ }^{*} 7.32$ & $19.8 \pm 1.0^{\mathrm{a}}$ & \\
\hline
\end{tabular}

${ }^{a, b}$ Averages followed by different letters on the same row differ statistically by Skott-Knott's test $(P<0.05)$.

Both FTIR and HPLC results consistently showed that CGA/5-CQA contents were higher for sun-grown coffee. Importantly, the HPLC analysis showed that the caffeine content of sun-grown coffee was at most equal to that in shade-grown coffee. Therefore, the highest FTIR spectra intensity observed at $2850 \mathrm{~cm}^{-1}$ in sun-grown coffee might be attributable to lipids only. It is generally considered that a higher lipid content implies better quality beans [24] [25].

Contradictory conclusions have been reached in previous studies of the correlation between sun exposure and CGA levels. In some cases, CGA was found to be favored by shading [41], whereas other studies obtained the opposite result, i.e., CGA was favored by sun [15]. Some studies reported a negligible correlation between CGA content and sun exposure [55]. It is worth emphasizing that CGA and sun exposure have a significant influence on the degree of maturation of fruits [56]. Overall, the available information leads us to conclude that CGA is influenced by different parameters related to the microclimate and local topography. In the present study, shading provided a local environment with higher humidity, that might have favored fermentation processes. A recent study reported that microbial fermentation was induced by water washing of sesame seeds (Sesanum indicum) and caused a drastic reduction in phenolic content [57]. Similar results have been observed in many fruits, vegetables, and beans [58]. Therefore, we propose that humidity could be responsible for the lower CGA values observed in our shade-grown coffee samples. As described in the literature lower 5-CQA content in roasted coffee beans is associated with a higher incidence of defects and imperfections (Black type) [24] [55]. However, the highest 5-CQA content, indicative of improved quality, was found here in sun-grown coffee and may have had a positive influence on beverage flavor [46] [59].

\subsection{Sensorial Analysis}

The average value of the grades attributed to the roasted-ripe beans was 77.90 
and 87.27 for shade-grown coffee and sun-grown coffee, respectively. This result confirms the beverages made with sun-grown coffee beans had both the best flavor and smell.

\section{Conclusion}

The results of the present study show that sun-grown coffee (C. canephora) produced in the Jaguaré city region, Espírito Santo State, Brazil, was of better quality than shade-grown coffee intercropped with rubber trees under periods of rainfall. From comparisons with the literature, which show different results depending on the set of parameters studied, we conclude that this is a specific characteristic of the studied site. PPO activity and the values obtained for EC and LK suggest that shade-grown coffee samples suffered damage due to the action of insets and microorganisms, thus inducing undesirable fermentation processes. These events are also responsible for higher amounts of stable free radicals observed in shade-grown coffee. Furthermore, the superior quality of sun-grown coffee, as indicated by sensorial analysis, was associated with higher lipid, CGA, and total sugar contents. The present report succeeded in correlating different physicochemical data, recorded from a range of experimental techniques, while evaluating the organoleptic quality of coffee beans grown under different shade conditions and roast processes. We envisage that the data analysis provided in the present study will contribute to advancing the use of physicochemical data in establishing protocols for future coffee bean quality control.

\section{Acknowledgements}

The authors acknowledge financial support from CNPq and FAPES Brazilian Government Agencies and also the Laboratório de Ciências Físicas, from Universidade Estadual Norte Fluminense, Rio de Janeiro, Brazil.

\section{Conflicts of Interest}

There are no conflicts to declare.

\section{References}

[1] Mondego, J.M., Vidal, R.O., Carazzolle, M.F., Tokuda, E.K., Parizzi, L.P., Costa, G.G. and Pereira, G.A. (2011) An EST-Based Analysis Identifies New Genes and Reveals Distinctive Gene Expression Features of Coffea arabica and Coffea canephora. BMC Plant Biology, 11, 1-22. https://doi.org/10.1186/1471-2229-11-30

[2] Mori, A.L.B., Kalschne, D.L., Ferrão, M.A.G., da Fonseca, A.F.A., Ferrão, R.G. and Benassi, M.T. (2016) Diterpenes in Coffeacanephora. Journal of Food Composition and Analysis, 52, 52-57. http://dx.doi.org/10.1016/j.jfca.2016.08.004

[3] ICO-International Coffee Organization (2016) Total Production by All Exporting Countries. http://www.ico.org/prices/po-production.pdf

[4] Bertrand, B., Boulanger, R., Dussert, S., Ribeyre, F., Berthiot, L., Descroix, F. and Joët, T. (2012) Climatic Factors Directly Impact the Volatile Organic Compound Fingerprint in Green Arabica Coffee Bean as Well as Coffee Beverage Quality. Food 
Chemistry, 135, 2575-2583. https://doi.org/10.1016/j.foodchem.2012.06.060

[5] Araújo, A.V., Partelli, F.L., Oliosi, G. and Pezzopane, J.M.R. (2016) Microclimate, Development and Productivity of Robusta Coffee Shaded by Rubber Trees and at Full Sun. Revista Ciência Agronômica, 47, 700-709. https://doi.org/10.5935/1806-6690.20160084

[6] Dandengo, M.C.J., Sousa, E.F., Reis, E.F. and Amaral, G.G. (2014) Crescimento e qualidade de mudas de café conilon produzidas em diferentes recipientes e níveis de sombreamento. Coffee Science, 8, 500-509.

[7] Alemu, M.M. (2005) Effect of Tree Shade on Coffee Crop Production. Journal of Sustainable Development, 8, 66-70. https://doi.org/10.5539/jsd.v8n9p66

[8] Tolessa, K., D’heer, J., Duchateau, L. and Boeckx, P. (2017) Influence of Growing Altitude, Shade and Harvest Period on Quality and Biochemical Composition of Ethiopian Specialty Coffee. Journal of the Science of Food and Agriculture, 97, 2849-2857. https://doi.org/10.1002/jsfa.8114

[9] Morais, H., Caramori, P.H., Ribeiro, A.M.A., Gomes, J.C. and Moreno, E.C. (2003) Produtividade de cafeeiros sob denso sombreamento de guandu em dois anos consecutivos. http://www.sbicafe.ufv.br/handle/123456789/1943/

[10] Bosselmann, A.S., Dons, K., Oberthur, T., Olsen, C.S., Raebild, A. and Usma, H. (2009) The Influence of Shade Trees on Coffee Quality in Small Holder Coffee Agroforestry Systems in Southern Colombia. Agriculture, Ecosystems \& Environment, 129, 253-260. https://doi.org/10.1016/j.agee.2008.09.004

[11] Beer, J., Muschler, D., Kass, D. and Somarriba, E. (1998) Shade Management in Coffee and Cacao Plantations. Agroforestry Systems, 38, 139-164. https://doi.org/10.1023/A:1005956528316

[12] Schroth, G., Krauss, U. and Gasparotto, L. (2000) Pests and Diseases in Agroforestry Systems of the Humid Tropics. Agroforestry Systems, 50, 199-241.

https://doi.org/10.1023/A:1006468103914

[13] DaMatta, F., Rena, A. and Zambolim, L. (2002) Departamento de Fitopatologia: Ecophysiology of Coffee Plantations Shaded and in Full Sun. The State of the Art Technologies in Coffee Production (Ecofisiologia de cafezais sombreados e a pleno sol. O estado da arte de ecnologias na produção de café). Universidade Federal de Viçosa, Brazil.

[14] Yobana, A.M., Pérez, M.E., Trifilio, F.G.M., Cruz, M. and Baymana, P. (2016) Sun vs. Shade Affects Infestation, Total Population and Sex Ratio of the Coffee Berry Borer (Hypothenemus hampei) in Puerto Rico. Agriculture, Ecosystems \& Environment, 222, 258-266. https://doi.org/10.1016/j.agee.2015.12.031

[15] Vaast P., Bertrand, B., Perriot, J.J., Guyot, B. and Génard, M. (2006) Fruit Thinning and Shade Improve Bean Characteristics and Beverage Quality of Coffee (Coffea arabica) under Optimal Conditions. Journal of the Science of Food and Agriculture, 86, 197-204. https://doi.org/10.1002/jsfa.2338

[16] Silva, C.F., Vilela, D.M., Cordeiro, C.S., Duarte, W.F., Dias, D.R. and Schwan, E.F. (2013) Evaluation of a Potential Starter Culture for Enhance Quality of Coffee Fermentation. World Journal of Microbiology and Biotechnology, 29, 235-247. https://doi.org/10.1007/s11274-012-1175-2

[17] Thapa, S. and Lantinga, E.A. (2017) Growing Coffee in the Shade: A Strategy to Minimize the Prevalence of Coffee White Stem Borer, Xylotrechus quadripes. Southerwestern Entomologist, 42, 357-361. https://doi.org/10.3958/059.042.0205

[18] Buechley, E.R., Sekercioglu, Ç.H., Atickem, A., Gebremichael, G., Ndungu, J.M., 
Mahamued, B.A., Beyene, T., Mekonnen, T. and Lens, L. (2015) Importance of Ethiopian Shade Coffee Farms for Forest Bird Conservation. Biological Conservation, 188, 50-60. https://doi.org/10.1016/j.biocon.2015.01.011

[19] Prete, C.E.C. (1992) Condutividade elétrica do exsudato de grãos de café (Coffea arabica) e sua relação com a qualidade da bebida. Ph.D. Thesis, Escola Superior de Agricultura Luiz de Queiroz, Piracicaba, Brazil.

[20] Carvalho, V.D., Chagas, S.J., Chalfoun, S.N., Botrel, N. and Juste, E.S.G. (1994) Relação entre a composição físico-química e química do grão beneficiado e qualidade de bebida do café. Pesquisa Agropecuária Brasileira, 29, 449-454.

[21] Redgwell, R. and Fischer, M. (2006) Coffee Carbohydrates. Brazilian Journal of Plant Physiology, 18, 165-174. https://doi.org/10.1590/S1677-04202006000100012

[22] Abrahão, A.A., Pereira, R.G.F.A., Borém, F.M., Rezende, J.C. and Barbosa, J.C. (2009) Classificação física e composição química do café submetido a diferentes tratamentos fungicidas. Coffee Science, 4, 100-109.

[23] Nascimento, E.A., Aquino, F.J.T., Nascimento, P.M., Chang, R. and Morais, S.L.A (2008) Composição química do café conillon em diferentes graus de torração. Ciência \& Engenharia, 16, 17-21.

[24] Franca, A.S., Oliveira, L.S., Mendonça, J.C.F. and Silva, X.A. (2005) Physical and Chemical Attributes of Defective Crude and Roasted Coffee Beans. Food Chemistry, 90, 89-94. https://doi.org/10.1016/j.foodchem.2004.03.028

[25] Farah, A., Monteiro, M.C., Calado, V., Franca, A.S. and Trugo, L.C. (2006) Correlation between Cup Quality and Chemical Attributes of Brazilian Coffee. Food Chemistry, 98, 373-380. https://doi.org/10.1016/j.foodchem.2005.07.032

[26] Ismail, I., Anuar, M.S. and Shamsudin, R. (2013) Effect on the Physico-Chemical Properties of Liberica Green Coffee Beans under Ambient Storage. International Food Research Journal, 20, 255-264.

[27] Gonis, J., Hewitt, D.G., Troup, G., Hutton, D.R. and Hunter, C.R. (1995) The Chemical Origin of Free Radicals in Coffee and Other Beverages. Free Radical Research, 23, 393-399. https://doi.org/10.3109/10715769509065260

[28] Pascual, E.C., Goodman, B.A. and Yeretzian, C. (2002) Characterization of Free Radicals in Soluble Coffee by Electron Paramagnetic Resonance Spectroscopy. Food Chemistry, 50, 6114-6122. https://doi.org/10.1021/jf020352k

[29] Flament, I. (2001) Coffee Flavor Chemistry. Wiley, John Wiley \& Songs Limited, Chichester.

[30] Blank, I., Pascual, E.C., Fay, L.B., Stadler, R.H., Yeretzian, C. and Goodman, B.A. (2002) Degradation of the Coffee Flavor Compound Furfuryl Mercaptan in Fenton-Type Model Systems. Journal of Agricultural and Food Chemistry, 50, 2356-2354. https://doi.org/10.1021/jf011329m

[31] Brezová, V., Slebodová, A. and Stasco, A. (2009) Coffee as Source of Antioxidants: An EPR Study. Food Chemistry, 114, 859-868. https://doi.org/10.1016/j.foodchem.2008.10.025

[32] Yeretzian, C., Pascual, E.C. and Goodman, B.A. (2012) Effect of Roasting and Grinding on Free Radical Contents of Coffee Beans Stored in Air. Food Chemistry, 131, 811-816. https://doi.org/10.1016/j.foodchem.2011.09.048

[33] Alvares, C.A., Stape, J.L., Sentelhas, P.C., Gonçalves, J.L.M. and Sparovek, G. (2014) Köppen's Climate Classification Map for Brazil. Meteorologische Zeitschrift, 22, 711-728. https://doi.org/10.1127/0941-2948/2013/0507 
[34] Dische, Z. (1962) Carbohydrate Chemistry: General Colors Reactions. Whistler, R.L. and Wolfram, M.L., Eds. Academic Press, New York.

[35] Ponting, J.D. and Joslyng, M.A. (1948) Ascorbic Acid Oxidation and Browining in Apple Tissue Extracts. Archives of Biochemistry and Biophysics, 19, 47-63.

[36] Goodman, B.A., Pascual, E.C. and Yeretzian, C. (2011) Real Time Monitoring of Free Radical Processes during the Roasting of Coffee Beans Using Electron Paramagnetic Resonance Spectroscopy. Food Chemistry, 125, 248-254. https://doi.org/10.1016/j.foodchem.2010.07.072

[37] AOAC-Association of Official Analytical Chemistry (1997) Official Methods of Analysis of AOAC. 16th Edition. AOAC, Gaitherburg.

[38] Cruz, C.D. (2013) Genes: A Software Package for Analysis in Experimental Statistics and Quantitative Genetics. Acta Scientiarum Agronomy, 35, 271-276. https://doi.org/10.4025/actasciagron.v35i3.21251

[39] CQI-Coffee Quality Institute-SCAA (2012) Standards and Protocols. http://www.coffeeinstitute.org/resources/scaa-standards-and-protocols/

[40] Pinto, A.V.D., Fernandes, S.M., Pires, T.C., Pereira, R.G.F.A. and Carvalho, V.D. (2001) Avaliação dos polifenóis e açucares em padrões de bebida do café torrado tipo expresso. Revista Brasileira de Agrociência, 7, 193-195.

[41] Somporn, S., Kamtuo, A., Theerakulpisutb, P. and Siriamornpun, S. (2012) Effect of Shading on Yield Sugar Content, Phenolic Acids and Antioxidant Property of Coffee Beans (Coffea Arabica L. cv. Catimor) Harvested from North-Eastern Thailand. Journal of the Science of Food and Agriculture, 92, 1956-1963. https://doi.org/10.1002/jsfa.5568

[42] Bellé, C., Kulczynsky, S.M., Basso, C.J., Kaspary, T.E., Lamego, F.P. and Pinto, M.A.B. (2017) Yield and Quality of Wheat Seeds as a Function of Desiccation Stages and Herbicides. Journal of Seed Science, 36, 63-70. https://doi.org/10.1590/S2317-15372014000100008

[43] Amorim, H.V. and Silva, O.M. (1968) Relationship between the Polyfenoloxidase Activity of Coffee Beans and Quality of the Beverage. Nature, 219, 381-382. https://doi.org/10.1038/219381a0

[44] Felton, G.W., Donato, K.K., Broadway, R.M. and Du, S.S. (1992) Impact of Oxidized Plant Phenolics on the Nutritional Quality of Dietary Protein to a Noctuid Herbivore, Spodoptera exigua. Journal of Insect Physiology, 38, 277-285. https://doi.org/10.1016/0022-1910(92)90128-Z

[45] Mazzafera, P., Gonçalves, K.V. and Shimizu, M.M. (2002) Extração e dosagem da atividade da polifenoloxidase do café. Scientia Agricola, 59, 695-700. https://doi.org/10.1590/S0103-90162002000400012

[46] Montavón, P., Duruz, E., Rumo, G. and Pratz, G. (2003) Evolution of Green Coffee Protein Profiles with Maturation and Relationship to Coffee Cup Quality. Journal of Agricultural and Food Chemistry, 51, 1328-2334. https://doi.org/10.1021/jf020831j

[47] Silverstein, M., Filipová, H., Volka, K., Delgadillo, I. and Davies, N.A. (2005) Qualitative Analysis of Green Coffee by Infrared Spectrometry. Fresenius Journal of Analytical Chemistry, 345, 327-332.

[48] Kemsley, E.K., Ruault, S.H., Jackson, M.A. and Bennett, G.A. (1995) Detection of Fungal Contamination in Corn: Potential of FTIR-PAS and DSR. Journal of Agricultural and Food Chemistry, 54, 321-326.

https://doi.org/10.1016/0308-8146(95)00030-M 
[49] Reis, N., Franca, A.S. and Oliveira, L.S. (2013) Discrimination between Roasted Coffee, Roasted Corn and Coffee Husks by Diffuse Reflectance Infrared Fourier Transform Spectroscopy. LWT-Food Science and Technology, 50, 715-722. https://doi.org/10.1016/j.lwt.2012.07.016

[50] Wang, N., Fu, Y. and Lim, L.T. (2009) Feasiblility Study on Chemometric Discrimination of Roasted Arabica Coffees by Solvent Extration and Fourrier Transform Infrared Spectroscopy. Journal of Food Science, 74, 385-391. https://doi.org/10.1111/j.1750-3841.2009.01173.x

[51] Paradkar, M.M. and Irudayaraj, J. (2002) Rapid Determination of Caffeine Content in Soft Drinks Using FTIR-ATR Spectroscopy. Food Chemistry, 78, 261-266. https://doi.org/10.1016/S0308-8146(02)00116-4

[52] Liang, N. and Kitts, D.D. (2015) Role of Chlorogenic Acids in Controlling Oxidative and Inflammatory Stress Conditions. Nutrients, 8, 1-20. https://doi.org/10.3390/nu8010016

[53] Illy, A. and Viani, R. (1996) Espresso Coffee: The Chemistry of Quality. Illy, A. and Viani, R., Eds. Academic Press, San Diego, 256.

[54] Farah, A. and Donangelo, C.M. (2006) Phenolic Compounds in Coffee. Brazilian Journal of Plant Physiology, 18, 23-36. https://doi.org/10.1590/S1677-04202006000100003

[55] Avelino, J., Barboza, B., Davrieux, F. and Guyot, B. (2007) Shade Effects on Sensory and Chemical Characteristics of Coffee from Very High Altitude Plantations in Costa Rica. Second International Symposium on Multi-Strata Agroforestry Systems with Perennial Crops: Making Ecosystem Services Count for Farmers, Consumers and the Environment, Turrialba, Costa Rica, 17-21 September 2007.

[56] Fagan, E.B., Souza, C.H.E., Pereira, N.M.B. and Machado, V.J. (2011) Effect of Time on Coffee Bean (Coffea sp) Growth in Cup Quality. Bioscience Journal, 27, 729-738.

[57] Ibukun, E.O. (2012) Fermentation Attenuates the Free Radical Scavenging and Antioxidant Activities of Sesame Seed (Sesanum indicum). International Journal of Pharmaceutics, 3, 324-331.

[58] Hertog, M.G.L., Hollman, P.C.H. and Vennema, D.P. (1992) Optimization of the Quantitative HPLC Determination of Potentially Anticarcinogenic Flavonoids in Vegetables and Fruits. Journal of Agricultural and Food Chemistry, 40, 1591-1598. https://doi.org/10.1021/jf00021a023

[59] Moreira, R.F.A., Trugo, L.C. and Maria, C.A.B. (2000) Compostos voláteis de café torrado-Parte II. Compostos alifáticos, alicíclicos e aromáticos. Química Nova, 23, 195-201. https://doi.org/10.1590/S0100-40422000000200010 